\title{
Intellectuals' Political Orientations: Toward an Analytical Sociology
}

\author{
Junpeng $\mathrm{Li}$ \\ Department of Sociology, Columbia University \\ 501 Knox Hall—MC 9649, 606 West 122nd Street, New York, NY 10027, U.S.A. \\ E-mail:j13023@columbia.edu
}

\begin{abstract}
This article surveys the field of the sociology of intellectuals, and calls for a move toward an analytical sociology. Topics covered are the definitions of intellectuals, the class nature of intellectuals, and the roles of intellectuals in society, in particular intellectuals' involvement in politics. This article then moves on to the literature on intellectuals' political consciousness, and makes a call for a shift from a moralistic mission to an analytical approach, and a shift from intellectuals as an "independent variable" to a "dependent variable."
\end{abstract}

Keywords: Intellectual, Sociology, Politics

\section{Introduction}

Intellectuals have been the subject of inquiry for sociology since its inception. The "big three" founders of sociology all write about intellectuals, from Karl Marx's (1844/2002) discussion of intellectuals' relationship with the working class to Émile Durkheim's (1893/1984) attribution of the rise of anomie to general education, and to Max Weber's (1919/1946, 1922/1963) analyses of religion and science as a vocation. The sociology of intellectuals as a field of study, however, has its ebbs and flows, and has often been perplexed, infringed, and hurt by normative missions. The Dreyfus Affair first gave the sociology of intellectuals legitimacy as a group with class-like consciousness appearing to be emerging in the first decade of the twentieth century, and the heated debates over the New Class appeared to give intellectuals a central stage in sociology in the 1970s, but the sociology of intellectuals has never achieved a status comparable to its subject of study. (Note 1) On the contrary, the sociology of intellectuals has often been subsumed into other fields of study, such as the sociology of knowledge and the sociology of science (Kurzman \& Owens, 2002, p. 63). Recently, the sociology of intellectuals has seen signs of revival. However, a number of issues remain both confusing and confused, which makes a critical review necessary as well as timely.

This article is intended as a brief review and critique of mainstream sociological studies of intellectuals. I first survey the efforts of sociologists to define intellectuals, then discuss the debates on whether intellectuals constitute a class. The next section focuses on the role of intellectuals in the society, in particular intellectuals' involvement in politics. Finally, I move on to the literature on intellectuals' political orientations, and make a call for a shift from moralistic missions to an analytical sociology.

\section{Who are the Intellectuals?}

Defining intellectuals is a notoriously tricky business. As Lewis Coser (1965/1970) notes, "Few modern terms are as imprecise as the term "intellectual"' (p. xv). One factor making "intellectual" a highly contested term is probably that any definition is ultimately a matter of self-construction, for various definitions are always proposed by intellectuals themselves (Bauman, 1992, p. 81). Indeed, many sociologists use "they" and "we" interchangeably when referring to intellectuals in their writings (Goldfarb, 1998; James, 1907/1912).

"Intellectual" as an adjective has long existed in the English world, but not until the early nineteenth century had it emerged as a noun, often referring to the faculties of the mind (Collini, 2006, pp. 17-18). The earliest use of the term as an indication of a group of persons was recorded in 1813 (p. 18).

The term first linked to various modern notions and conveying a collective identity is "intelligentsia," which originated in nineteenth-century Russia and referred to persons who (1) had a deep concern for matters of public interest; (2) had a sense of personal responsibility for the state; (3) tended to view political and social issues as moral ones; (4) felt obligated to seek ultimate logical conclusions; and (5) were convicted that something went wrong and needed to be fixed (Confino, 1972, p. 118). "Intellectuals" as a term rose to prominence at the end of the nineteenth century, both in English and French, with the eruption of the Dreyfus Affair (Collini, 2006, pp. 20-21; Kadushin, 1974, p. 4). It was through references to the Dreyfus Affair that "intellectuals" in its plural 
form gained currency (Collini, 2006, p. 21).

The multitudinous definitions of intellectuals often see and combine different dimensions of intellectuals: their personal characteristics, their output, their positions in society, and their general social roles or functions. I survey the existing definitions according to these four dimensions.

In terms of characteristics, intellectuals are often seen as persons who are well-educated or, in modern sociological language, possess a high amount of "cultural capital." While many scholars have tried to make distinctions between "intellect" and "intelligence" (Hansen, 1969, pp. 312-313; Hofstadter, 1963, p. 25), unsurprisingly, intellectuals have often been equated with people of intelligence, or "men of letters" (Tocqueville 1856/1998, p. 195). Jacques Barzun (1959) identifies intellectuals as those who "consciously and methodically employ the mind" (p. 5). Richard Hofstadter (1963) thinks of intellectuals as persons who live for rather than off ideas and whose thinking is marked by "disinterested intelligence, generalizing power, free speculation, creative novelty, radical criticism" (p. 27).

Intellectuals can be viewed as persons with a deep concern of society or a sense of responsibility. Edward Shils $(1958 / 1972)$ identifies intellectuals as a minority of persons in every society with "an unusual sensitivity to the sacred, an uncommon reflectiveness about the nature of their universe and the rules which govern their society" and with "interior need to penetrate beyond the screen of immediate concrete experience" (p. 3). Acknowledging that intellectuals are often a heterogeneous group, Coser (1965/1970) nevertheless offers generalizations of intellectuals as those who exhibit "a pronounced concern with the core values of society" (p. xvi) and "tend to scrutinize the received ideas and assumptions of their times and milieu" (p. xviii).

Intellectuals are often seen as those whose output involves culture or ideas, or in Julien Benda's (1927/1928, p. 43) words, whose pursuits are not practical aims. Joseph Schumpeter (1942/1950) defines intellectuals as "people who wield the power of the spoken and the written word ... [in] the absence of direct responsibility for practical affairs" (p. 147). Robert Brym (2001) understands intellectuals as "people whose main activities involve producing, evaluating, and distributing culture" (p. 7631). Seymour Martin Lipset (1960/1981) defines intellectuals in terms of occupations, and refers to intellectuals as "all those who create, distribute, and apply culture, that is, the symbolic world of man, including art, science, and religion," with the creators of culture, namely philosophers, artists and authors, occupying the core, art performers, teachers and reporters functioning as distributors, and professionals such as physicians and lawyers at the periphery (p. 311). Reinhold Niebuhr (1960) sees intellectuals as "the more articulate members of the community, more particularly those who are professionally or vocationally articulate, in church and school, in journalism and the arts" (p. 302). Hansen (1969) combines attitudinal and vocational dimensions and treats as an intellectual "one who tends to manipulate and interiorize the symbolic rather than the material environment as the principal means of ontological self-affirmation" (p. 314).

Intellectuals have also been defined in terms of their position in society. Some broad definitions treat all college and university graduates as intellectuals (James, 1907/1912, p. 319). In the United States, those who frequently contribute to Commentary or the New York Review of Books are often considered to be intellectuals (Kadushin, 1974, p. 5).

From a more structural viewpoint, a number of scholars have defined intellectuals according to certain functions or roles they undertake or should undertake. Treating "intellectuals" and "intelligentsia" as interchangeable notions, Karl Mannheim (1936) sees intellectuals as "social groups whose special task ... is to provide an interpretation of the world for [the society in which they live]" (p. 10). Charles Kadushin (1974) examines "elite intellectuals" and defines them as experts "in dealing with high-quality general ideas on questions of values and esthetics and who [communicate their] judgments on these matters to a fairly general audience" (p. 7). Antonio Gramsci has a much broader notion of intellectuals and uses "intellectual" to "designate anyone whose function in society is primarily that of organizing, administering, directing, educating or leading others" (Forgacs 1988/2000, p. 300). Jeffrey Goldfarb (1998) examines intellectuals in democratic societies and views them as "special kinds of strangers, who pay special attention to their critical faculties, who act autonomously of the centers of power and address a general public, playing the specialized role in democratic societies of fostering informed discussion about pressing societal issues" (p. 37). Edward Said (1994) argues that while so-called intellectuals do otherwise, the true intellectual is the dissenter who speaks truth to power (pp. 85-102). Katherine Verdery (1991a) treats intellectuals as "sometime occupants of a site that is privileged in forming and transmitting discourses, in constituting thereby the means through which society is 'thought' by its members, and in forming human subjectivities" (p. 17). Verdery's conceptualization of intellectuals reflects an emphasis on intellectuals' activities, rather than intellectual traits. From this perspective, intellectuals are viewed as those who 
occupy a fluid, often contentious, space or field.

The problem with all the above efforts to define intellectuals, whether as a personal characteristic or a social role, is that "intellectuals"are indeed a social construct that is historically and culturally contingent. The act of defining intellectuals itself involves inclusion and exclusion. As Bauman (1992) suggests, defining intellectuals functions more as a project or mobilizing call rather than an empirical inquiry, as it aims to demonstrate the social value of the intellectual mission and calling.

Pierre Bourdieu (1984/1988, pp. 256-270) rejects the notion that there can be an "objective" definition of intellectuals, as the action of defining is a matter of symbolic power. In other words, who are the intellectuals is itself a site or object of struggle within cultural fields. To Bourdieu, what truly matters and begs for explanation is the struggle itself, not its product, i.e. the definition of intellectuals. In line with Bourdieu's argument, Michel Foucault (1977/1994) proposes to replace the traditional intellectual who transcends her class roots and defends universal values by the expert specialist, and insists that no value is untouched by power.

Bourdieu's and Foucault's opinions are becoming increasingly influential among sociologists (Note 2), as more and more studies have moved their attention away from the definition of intellectuals to the struggle for symbolic power, as well as the implications of the struggle (Barber, 1998; Eyal, 2003; Eyal, Szelényi \& Townsley, 1998; Judt, 1992; Kurzman, 2008).

\section{From Class to Field: Do Intellectuals Constitute a Class?}

A question haunting the sociology of intellectual is the class nature of intellectuals. In other words, do intellectuals constitute a social class? There exist three broad analytical traditions: intellectuals as class-in-themselves, intellectuals as class-bound, and intellectuals as class-less (Brym, 2001; Kurzman \& Owens, 2002; Walker, 1979b).

Marx never spells out a systematic theory of intellectuals (Note 3), nor does he offer a formal definition of class, but his (often ambivalent) theory, in which intellectuals are grounded in class struggles, lays the theoretical foundations of waves of successive efforts to locate intellectuals in social strata. Early Marxists see intellectuals as (at least potentially) members of the proletariat class under capitalism (Brym, 2001, p. 7632), although some critics accuse Marx of intending to replace the real proletariat class with intellectuals and to exploit the workers (King \& Szelényi, 2004, p. vii). However, a number of subsequent Marxists, including Vladimir Lenin (1902/1975) and Mao Tse-tung (1926/1965), are upset with intellectuals' "failure" to be radicalized and place them (at least some of them) within the petty (petite) bourgeoisie.

The Dreyfus Affair in the 1890s and early 1900s, later known as "the protest of the intellectuals" (Franz, 2007, p. 98), gave the birth of the modern "intellectual" (Cahm, 1996, p. 69; Coser 1965/1970, pp. 215-225; Kritzman 2006, p. 363). For the first time in human history, intellectuals regarded themselves as a universal coherent social group that constituted a class:

In our democracy ... we [intellectuals] are the only permanent presence that corresponds to the aristocracy in older countries. We have continuous traditions, ... [and] we stand for ideal interests solely .... We ought to have our own class consciousness. "Les intellectuals!" (James 1907/1912, p. 319)

This was not merely the case for France - intellectuals gained a global identity and played a direct role in the wave of democratization prior to World War I (Kurzman, 2008). In the United States, revulsion with the Vietnam War united intellectuals on the left and a "sense of solidarity" arose among them (Coser 1965/1970, p. xi).

The most prominent and explicit effort to conceptualize intellectuals as a class has come from New Class theorists who inspired heated debates in the 1960s and 1970s (Bruce-Briggs, 1979; Kellner \& Heuberger, 1992; Walker, 1979a). This wave of New Class theory had its roots in the theories of the bureaucratic-technocratic class from the 1930s to 1950 s, which claimed that a new dominant technocratic-bureaucratic class was emerging in the West and/or the Soviet Union (Szelényi \& Martin 1988, pp. 652-655). Coming from different political spectrums, Daniel Bell, Alvin Gouldner, George Konrád and Ivan Szelényi are among the most important New Class theorists.

Bell (1973/1976, 1979/1991) examines intellectuals within his postindustrial framework. With the expansion of higher education and increasing role of information and knowledge, argues Bell, there was a breakup of the class system of capitalism, and several groups emerged and formed a coherent class. David Bazelon (1967) has a similar argument, although he focuses more exclusively on the occupational dimension.

During this period, the emerging neoconservatives also notice the rise of a new class. Irving Kristol (1978), a major founder of the neoconservative movement, writes: 
Today there is a new class hostile to business in general, and especially to large corporations. As a group, you find them mainly in the very large and growing public sector and in the media. They share a disinterest in personal wealth, a dislike for the free-market economy, and a conviction that society may best be improved through greater governmental participation in the country's economic life. They are the media. They are the educational system. Their dislike for the free-market economy originates in their inability to exercise much influence over it so as to produce change. In its place they would prefer a system in which there is a very large political component. This is because the new class has a great deal of influence in politics.

This kind of concern over the tendency of intellectuals toward the left and their influence over politics was not new, and F.A. Hayek (1948/1949) expresses a similar concern about intellectuals' embrace of socialism three decades ago.

Writing from the position of political left, Gouldner (1978a) provides probably the most radical, optimistic, and controversial picture of the rise of a universal New Class:

In all countries that have in the twentieth century become part of the emerging world socio-economic order, a New Class composed of intellectuals and technical intelligentsia ... enter into contention with the groups already in control of the society's economy .... A new contest of classes and a new class system is slowly arising in the third world of developing nations, in the second world of the USSR and its client states, and in the first world of late capitalism of North America, Western Europe, and Japan. (p. 153)

To Gouldner, the New Class is a "flawed universal class":

The New Class is elitist and self-seeking and uses its special knowledge to advance its own interests and power .... Yet the New Class may also be the best card that history has presently given us to play. (p. 159)

A Marxist sociologist, Gouldner (1978a, p. 159) sees commonalities in intellectuals' relationships with the means of production and cultural capital. What makes the New Class powerful is its culture of careful and critical discourse (CCD), a "historically emancipatory rationality" (Gouldner, 1978b, p. 379), which unites intellectuals and technical intelligentsia (Gouldner, 1978a, pp. 176-180). The emancipatory class "subverts all establishments, social limits, and privileges, not excluding its own" (Gouldner, 1978b, p. 379), and has a potential to become a dominant class.

Around the same period, Konrád and Szelényi (1979) conduct a similar study of intellectuals in Central Europe. Konrád and Szelényi have a similar notion of the New Class, which was composed of intellectuals and technocrats. According to Konrád and Szelényi, the workers, the class that Marx envisions to dominate in a socialist society are de facto powerless, and are the most underprivileged class, at least in socialist Central Europe. Instead, intellectuals are on the road to power and will be, if not already are, the ruling class. What set intellectuals apart from other classes is their monopoly on "teleological knowledge" (Szelényi, 1982, p. S306), the knowledge that is "necessary to setting and implementing goals for society, knowledge of the laws of social development and of the path to progress" (Verdery, 1991b, p. 429), which stems from "rational redistribution" (Konrád \& Szelényi, 1979, p. 53), the legitimating myth of the political system.

Discussions on the New Class became less visible in the 1980s. As King and Szelényi (2004, p. xiii) note, more than a century had passed since the term "New Class" was first used by Mikhail Bakunin around 1870, "New Class theorizing is still in shambles." There are several explanations for its loss of attraction for sociologists. First, sociologists often have difficulty reaching an agreement on what constitutes the New Class. As Bell (1979/1991) observes, the "New Class" is "a linguistic and sociological muddle" and often involves with two directions: the rise of a new social stratum and the "stridency of a cultural attitude" (p. 144). It appears that those on the political left tend to approach the New Class through the lenses of the former, while those on the political right often pay more attention to the latter direction. While often intertwined, these two processes do not necessarily overlap. Second, New Class sociologists have not reached a consensus on the composition of the New Class. The candidates that sociologists have come up with include humanist intellectuals, bureaucrats, professionals, technocrats, engineers, managers, and radical or adversary-culture intellectuals, whose definitions are highly contested in their own right (Brint, 1984; Kellner \& Heuberger, 1992; King \& Szelényi, 2004, p. xiii; Mills, 1951, pp. 291-292). Third, it is unclear as to how the New Class will ultimately obtain power, if it has not achieved that yet. Does the New Class obtain class power through the structural emergence of a postindustrial society and changes in techno-economic order (Bell 1973/1976, 1979/1991), the rise of an information age (Brooks, 2000), its control over media and educational system (Kristol, 1978), its action of elaborating and disseminating ideas (Wright, 1979, p. 193), its culture of careful and critical discourse (Gouldner, 1978a, 1978b), knowledge (Drucker, 1969) or "teleological knowledge" (Konrád \& Szelényi, 1979; Szelényi, 1982) or 
"symbolic domination" (Martin \& Szelényi, 1987), the progress of the adversary culture (Podhoretz, 1979), or educational status (Bazelon, 1967)? What type of knowledge gives the New Class distinction? How universal is the New Class? Whose interest does the New Class serve (Ehrenreich \& Ehrenreich, 1979; Wright, 1979)? Does it become dominant in the capitalist West or Soviet-type societies (King \& Szelényi, 2004, p. xiii)? How exclusive is the New Class? Is it only composed of intellectuals on the left? How does the New Class transform its knowledge or cultural capital into political power? How revolutionary is the New Class? These are all unsettled questions, and different New Class sociologists often have conflicting answers, emphasizing either structure or agency (King \& Szelényi, 2004, pp. xiii-xiv; Szelényi \& Martin, 1988). What is more, many sociologists have come to question the existence of a New Class (Brint, 1984; Wrong 1983/1998) or whether it is coming to power (Hacker, 1979). Steven Brint (1984) compares a series of views of the New Class with those of business owners and executives, and finds no substantial differences. The biggest problem with the "New Class" is that, as summarized by Paul Kingston (2000), it is a concept appearing to be driven by "ideological passion" (p. 180) and "float free of any empirical anchor" (p. 184).

More profoundly, the trajectory of social theory since the 1980s has had profound influences on the way sociologists look at the New Class thesis. Postmodernism (Agger, 1991) has forced or propelled sociologists to reexamine the ontological status of the New Class, and the class has been one of the major targets of deconstruction. Although postmodernism has never achieved a dominant status, many theoretical elements have been widely accepted, such as the sentiment of anti-essentialism (Fuchs, 2001). Some sociologists even go further and declare the death of social classes or the arrival of a classless society (Kingston, 2000; Waters 1991).

The history of theories of intellectuals as classless is as long as that of class theories. Mannheim's classic study of the sociology of knowledge, Ideology and Utopia (1929/1936), is probably the most influential statement in this tradition. According to Mannheim, intellectuals do not constitute a social class or even "an appendage to a class," nor do they have the capacity of coherent group action (p. 155), for they do not have enough common interests and there is a high degree of heterogeneity among them. Instead, intellectuals are "members of a relatively classless stratum which is not too firmly embedded in the social order" (p. 154). Because intellectuals are recruited from different social classes, the various views or outlooks associated with the different classes tend to be attached to intellectuals. Therefore, intellectuals are "determined in their outlook by this intellectual medium which contains all those contradictory points of view" (p. 157). Borrowing Alfred Weber's terminology, Mannheim treats intellectuals as a "socially unattached" or "free-floating" stratum, and argues that "a sociology which is oriented only with reference to social-economic classes will never adequately understand this phenomenon" (p. 155).

However, Mannheim does not conclude that intellectuals are a rootless stratum, as education binds intellectuals together and subjects intellectuals to "the influence of opposing tendencies in social reality" (p. 156). Therefore, for Mannheim, intellectuals do not constitute a class, but transcend class. Mannheim believes that the "free-floating intellectuals" will fulfill their potential by creating a "dynamic synthesis" of the ideologies of other groups (p. 159).

Mannheim is not alone. David Caute (1966) insists that "the sociological approach .... while of cardinal importance in analysing proletarian or peasant behaviour, is of strictly limited use when applied to intellectuals .... The act of [intellectuals'] political affiliation remains one of personal conviction, personal psychology, personal choice" (pp. 17-19). By asserting that intellectuals put "cultural considerations before social ones", Talcott Parsons (1969, p. 4) practically rejects the class approach to intellectuals. Ladd and Lipset (1975) maintain that "there are factors in the social role of intellectuals which result in their persistent position as social critics," and the capacity of intellectuals for criticism and creativity enables intellectuals to transcend their class origins (pp. 132-133).

There has been a branch of theory in the middle-intellectuals as class-bound (Kurzman \& Owens 2002). According to this theory, intellectuals are neither a social class nor classless; rather, intellectuals are a loose group consisting of different social origins and cultural backgrounds. Gramsci (1932/2000, p. 304) famously declares that "all men are intellectuals," rejecting the notion that intellectuals constitute an autonomous social class. A Marxist and writing in prison in the early 1930s, Gramsci has a surprisingly "modern" understanding of intellectuals. He sees an "intellectual" as a position, and points out that even manual tasks can have a creative and thinking dimension. As a result, Gramsci rejects the existence of particular characteristics that unify intellectuals or intellectual activities as a class. The meaning and status of intellectuals are historically situated and socially embedded.

While insisting that intellectuals have the potential for critical reflection, Gramsci (1932/2000) rejects 
Mannheim's understanding of intellectuals as free-floating thinkers and proposes the thesis of "collective intellectuals" (Note 4), insisting on the social structure's imprint on intellectuals' ideology and consciousness (pp. 309-311).

Gramsci explicitly points out that every class has its own intellectuals:

Every social group, coming into existence on the original terrain of an essential function in the world of economic production, creates together with itself, organically, one or more strata of intellectuals which give it homogeneity and an awareness of its own function not only in the economic but also in the social and political fields. (p. 301)

The French sociologist Bourdieu has great contributions to the study of intellectuals. With respect to intellectuals' class natures, Bourdieu stands in the middle. Of particular importance here is his understanding of cultural capital, symbolic violence, fields of cultural production, and field of power. According to Bourdieu (1979/1984), various intellectuals are tied together by cultural fields, and different positions have different endowments of economic, social and cultural capital, as well as values, ideas, and tastes.

Ron Eyerman (1994) also rejects both class and classless theses, and proposes "a processual conception of intellectuals which is sensitive to both phenomenological and structural points of view" (p. 3). He incorporates Anthony Giddens's structuration theory, and "takes into account the historically structured constraints on the possibilities of action and the desires of individuals and collectives to redefine and reinterpret those constraints." Based on his previous work on social movements, Eyerman pays particular attention to movement intellectuals - "individuals who gain the status and the self-perception of being 'intellectuals' in the context of their participation in political movements rather than through the institutions of the established culture" (p. 15).

The fall of the Berlin Wall in 1989 and the subsequent collapse of communist regimes in Central and Eastern Europe in the early 1990s provided a unique to reexamine the New Class thesis. Many sociological studies notice the role played by intellectuals in bringing down communism and the rise of intellectuals in power in this region (Eyal, 2003; Eyal et al., 1998; Kennedy, 1991; King \& Szelényi, 2004; Torpey, 1995). This wave of research abandons the rigidity of the old New Class thesis, and incorporates theoretical insights from Giddens, Bourdieu and Foucault, along with empirical precision.

\section{Civility versus Subversion: Intellectuals and the Social Order}

Social scientists have never stopped discussing and proposing intellectuals' role in society, and the body of literature is massive. This section is only intended to provide a sketch of the most influential remarks. It should be noted that the question of what intellectuals have done is beyond the scope of this section, which only focuses on theoretical discussions of the relationship between intellectuals and the social order.

In 1987, The Last Intellectuals, written by the historian Russell Jacoby, provoked heated discussions about the role of intellectuals. Jacoby declares that the university is wrecking intellectuals, for the university system in America is monopolizing intellectuals and independent intellectuals are disappearing. "A specter haunts American universities or, at least, its faculties: boredom," bemoaned by Jacoby (1987, p. xiii).

In the same year, in The Closing of the American Mind (1987), the philosopher Allan Bloom expresses a starkly different view: leftist intellectuals are wrecking the university. Bloom is deeply troubled by the intellectuals' engagement in politics:

Just as in politics the responsibility for the fate of freedom has devolved upon our regime, so the fate of philosophy in the world has devolved upon our universities, and they are related as they have never been before. The gravity of our given task is great, and it is very much in doubt how the future will judge our stewardship. (p. 382)

To discuss the role of intellectuals, the best starting point is probably Jaffrey Goldfarb's (1998) Civility and Subversion. In this book, Goldfarb asks a question: is intellectuals' role cultivating civility in public or promoting the subversion of restrictive common sense? This is indeed a central question that social scientists have never stopped asking and debating. The two directions - civility and subversion-represent two fundamentally different views of the role of intellectuals in the society. While George Orwell"s famous saying that "no ordinary man could be such a fool" (cited in Misztal, 2007, p. 15) has many followers who insist on a "Puritan" or "civilian" vision of intellectuals, at least equally many others are disappointed by the institutionalization of the intellectual life and call for intellectuals' involvement in politics, which can be seen as a "subversive" vision of intellectuals.

Shils (1958/1972, pp. 17-21) identifies five historical traditions in forming the relations of intellectuals to 
authority: scientism, romanticism, apocalypticism, populism, and anti-intellectualism. (Note 5) This can serve as the framework for analyzing intellectuals' role in society.

The tradition of scientism "denies the validity of tradition as such; it insists on the testing of everything which is received and on its rejection if it does not correspond with the "fact of experience"' (p. 18). Most scientists and many science-oriented academics are situated within this tradition.

The romantic tradition "values originality ... in contrast with the stereotyped and traditional actions of the philistine" (p. 18). Although there is a certain antagonism between scientism and romanticism, they share a common dedication to the ultimacy of individual experience, and a deep antagonism toward authority and conventions. The romantic intellectuals are mostly artists, journalists, and independent writers.

The apocalyptic tradition "draws much from scientism and romanticism, but ... rests on one much older, namely the apocalyptic or millenarian tradition" (p. 19). The apocalyptic intellectuals believe that the world is full of injustice which is deemed to come to an end, and intellectuals play a crucial role in bringing up a better world. This tradition has its origin in the Old Testament, however, "its true recipients are the modern revolutionary movements and above all the Marxian movements" (p. 19). Early Marxists often see intellectuals as the vanguard of the proletariat, as stated by Marx (1844) himself, "Philosophy cannot realize itself without the transcendence [Aufhebung] of the proletariat, and the proletariat cannot transcend itself without the realization [Verwirklichung] of philosophy" (p. 182). The realization of philosophy is of course carried out by intellectuals. Gramsci's (1932/2000) concept of "organic intellectuals" appears to fit this tradition as well.

Populism is "a belief in the creativity and in the superior moral worth of the ordinary people, of the uneducated and unintellectual; it perceives their virtue in their actual qualities or in their potentialities" (Shils, 1958/1972, p. 20).

The last tradition, antiintellectualism, believes that "excessive intellectual analysis and discussion can erode the foundations of order" (p. 21). The burning of the books and burial of the scholars by the first emperor of China and Thomas Hobbes's accusation of intellectuals in bringing about the English civil war are two prominent historical examples.

It should be noted that there are no clear-cut boundaries among these five traditions. Indeed, when social scientists, themselves intellectuals, illustrate the role of intellectuals, they almost always combine different elements of these historical traditions. Marxism, for example, while drawing heavily from apocalypticism, is at once tinted by all the other traditions, in its hope in human emancipation, in the suppression of intellectuals in communist Soviet Union and China, in its being regarded as a "socialist science" in China, and in the Up to the Mountains and Down to the Villages Movement (shangshan xiaxiang) in China.

In The Treason of the Intellectuals, one of the founding works of the sociology of intellectuals, Julien Benda (1927/1928) harshly criticizes what he sees as the decadence of intellectuals of his generation, for they have abandoned their attachment to and pursuit of the pure scholarly ideals. Benda argues that intellectuals should stop thinking in terms of collective passions and concentrate instead on transcendental values. Intellectuals to Benda are disinterested guardians of truth.

In his famous Reith Lectures, Said (1994) sketches the role of the intellectual as 'outsider, 'amateur,' and disturber of the status quo" (p. x). This is obviously an ideal type, as Said (1994: xv) severely criticizes the intellectuals who provide authority with their labor while gaining great profit. According to Said, intellectuals' responsibility dictates that they "speak the truth to power," representing the right course of action "where it can do the most good and cause the right change" (p. 102). Noam Chomsky (1967) is on Said's side, maintaining that intellectuals' role is to "expose the lies of governments, to analyze actions according to their causes and motives and often hidden intentions."

\section{Toward a Analytical Sociology}

As Kadushin (1974) observes, "There are almost as many works about intellectuals as there are intellectuals" (p. 3). The problem is that, as Karabel (1996) maintains, the existing body of literature has often taken a moralistic approach rather than an analytical one, and has treated intellectuals "not as they actually are, but as they should be" (p. 205). By prejudging intellectuals' political consciousness, we miss the opportunity to explore a dimension that begs for explanation.

In addition, we have learned a great deal about intellectuals' political consciousness and orientation, as well as the roles intellectuals have played in historical situations, but we know much less about the genesis and formation of intellectuals' political consciousness and ideology. Of course, sociologists have long been interested in the political attitudes and ideology of intellectuals, but what is lacking is a more comprehensive theory that 
pays attention to both micro and macro dimensions in shaping political ideology.

Among the few existing, often implicit, studies of the formation of intellectuals' political consciousness, a structuralist approach has generally been taken.

Class is probably the most prominent concept in accounting for intellectuals' political orientations. Although Marx and Engels (1932/1970) do not propose a comprehensive theory of intellectuals, their idea that class positions shape political ideology as part of the superstructure has inspired many sociologists to explain intellectuals' political orientations by tracing their class origins. It is also worth noting that Marx views ideology as a set of somewhat obscured or falsified beliefs deliberately imposed by the ruling class.

In Ideology and Utopia, Mannheim (1929/1936) offers one of the earliest manifestos for the sociology of knowledge and intellectuals. In this book, Mannheim lays the theoretical foundation for a "theory of the social determination of knowledge" without sacrifying epistemological insights (pp. 266-290). Although Mannheim was never a full-fledged Marxist, his theory of knowledge is heavily tinted with Marxism. While less determinate than Marx's view, Mannheim insists that "the world of our thought is affected by" the relationships between "the economic structure of a society and its legal and political organization" (cited in Zeitlin, 2001, p. 370). In his empirical research, Mannheim (1927/1953) emphasizes the social background of ideas' "carriers"-intellectuals - and insists a determinate relationship between intellectuals and social knowledge. Although Mannheim's notion of social context is broader than Marx's class position and includes factors such as generational differences (Mannheim, 1928/1952) and group dynamics (Mannheim, 1929/1936, p. 3), his thesis that social existence determines social consciousness is clearly derived from Marxism.

As stated above, Bourdieu (1966/1969, 1979/1984, 1984/1988) offers a great number of theoretical tools for studying intellectuals. The most relevant notion is the field of power. Bourdieu studies a variety of fields of cultural production and looks at how each leads to a distinct form of power. Different groups have distinct advantages in terms of endowment of resources, including cultural, political, and social capital. With these resources, different intellectual groups compete for power. According to Bourdieu, an intellectual's political orientation and taste are derived from her situation of privilege, which forms her distinct intellectual habitus. Bourdieu rejects the notion that an intellectual can develop her political attitude beyond her social position, and insists that the former cannot be reduced to the latter, for the intellectual field is a site of struggle for symbolic dominance and cannot be prefixed. Bourdieu also pays attention to the internal differentiation of intellectuals, which is the result of different types of resources they have and positions they occupy. The core idea-the intellectual field - is a site of different combination of endowments and is made up of actors taking up various intellectual positions (Bourdieu, 1966/1969).

Jerome Karabel (1996) proposes a series of testable theories of intellectual radicalism. Among the factors that lead intellectuals to political opposition are: (1) the presence of well-organized and politically radical subordinate social groups; (2) the absence of a strong business class; (3) a high ratio of "relatively unattached" intellectuals to those employed by large-scale organizations; (4) a moderately repressive regime that lacks the means and/or the will to stamp out dissent; (5) weakness or division within the ruling group; (6) challenges from the international scale; (7) sharp boundaries among social groups; and (8) historical and cultural repertories of resistance to authority (pp. 211-214).

Similarly, Robert Brym (2001) divides the factors that influence an intellectual's political attitude into three dimensions: social origins, economic opportunities, and political opportunities (p. 7633). In other words, an intellectual's political attitude is determined or affected by her family background, economic well-being, national political culture, and the relative vulnerability or openness of the polity.

Based on his theory of conflict sociology, Randall Collins $(1998,2005)$ analyzes the development of philosophical schools, and shows how intellectuals gain reputations by successfully competing for attention in intellectual circles. (Note 6) Although Collins does not directly deal with intellectuals' political ideology, his theory sheds light on how internal differentiation of ideas among intellectuals arises. Collins's theory is rooted in micro-level mechanisms of emotional energy and scales up through the idea of networks. However, it is still an externalist theory, and treating intellectual choices as strategic moves does not satisfactorily tell us where these strategies come from and how intellectuals are guided by their beliefs.

We can also find clues from reference group theory, which flows from George Herbert Mead's (1934, pp. 154-157) idea of the "generalized other." It tells us that an individual often evaluates her situation and forms her views against a comparative collectivity (Merton \& Kitt, 1950; Singer, 1981). Reference group theory directs our attention to the social context of a person's normative orientation and has inspired many social science studies covering a variety of topics (Smith, 1998; Sunstein, 2009). The problem is that it does not offer sufficient 
mechanisms and does not tell us how people are drawn to others, or as Rueschemeyer (2009) points out, it fails to inform us "under which conditions in any particular case who looks to whom with an impact on which standards of judgment" (p. 12).

There are more scattered explanations, such as functions of different social systems (Barber, 1998), national contexts (Fourcade, 2009; Ringer, 1969), network connections (Kadushin, 1974), unsatisfying conditions of employment (Nozick, 1986; Schumpeter 1942/1950), collective intellectual mentality and subculture (Bourdieu, 1999; Hollander, 1981), socialization including family, educational, and professional experiences (Camic, 1983), symbolic boundary maintaining (Lamont, 1992), and polarization through the interaction among those like-minded (Sunstein, 2009). But on the whole, the existing body of literature tends to treat intellectuals as a monolithic block and little has been offered to explain the formation, differentiation, and polarization of intellectuals' political orientations. If, as Said (1994, p. 22) writes, intellectuals always stand between loneliness and alignment, then this is in need of explanation.

Although most studies cited above reject Marxist class determinism and claim to leave room for contingency and contexts, with the exception of Burdieu, Camic, Collins and Lamont, a structuralist tenet, or externalist bias, is still visible. In other words, intellectuals' political consciousness and ideas are seen as formulated in accordance with their positions in social structure. The problem stems from the treatment of political consciousness as a coherent ontological entity, which renders a study static and leaves little room for agency.

Recently, a few sociologists have called for a "new sociology of ideas" (Camic \& Gross, 2001; Gross, 2008) and moved their attention to micro dimensions. Although the majority of this literature is meant to explain intellectual tastes and pursuits rather than political consciousness, its call for the study of ideas as an end, its rejection of the internal/external distinction, its insistence on contextualism, and its insistence on the importance of an intellectual's social circles (Camic \& Gross, 2001) can equally shed light on our understanding of the formation of political orientations. The new wave of thinking is relatively recent, and the empirical studies have been mostly on individual intellectuals. More empirical cases are obviously needed, and the theoretical model is to be evaluated and developed. However, the message is clear- now is time to move from moralistic missions to an analytical sociology.

\section{References}

Agger, B. (1991). Critical theory, poststructuralism, postmodernism: Their sociological relevance. Annual Review of Sociology, 17, 105-131.

Barber, B. (1998). Intellectual pursuits: Toward an understanding of culture. Lanham, MD: Rowan \& Littlefield.

Barzun, J. (1959). The house of intellect. New York: Harper \& Brothers.

Bauman, Z. (1992). Love in adversity: On the state and the intellectuals, and the state of the intellectuals. Thesis Eleven, 31, 81-104.

Bazelon, D. T. (1967). Power in America: The politics of the New Class. New York: New American Library.

Bell, D. (1973/1976). The coming of post-industrial society: A venture in social forecasting. New York: Basic Books.

Bell, D. (1979/1991). “The New Class: A muddled concept.” In The winding passage: Sociological essays and journeys. New Brunswick, NJ: Transaction. pp. 144-164.

Benda, J. (1927/1928). The treason of the intellectuals. New York: William Morrow.

Berman, M. (1982). All that is solid melts into air: The experience of modernity. New York: Penguin.

Bloom, A. (1987). The closing of the American mind. New York: Simon \& Schuster.

Bourdieu, P. (1966/1969). Intellectual field and creative project. Social Science Information, 8, 89-119.

Bourdieu, P. (1979/1984). Distinction: A social critique of the judgment of taste. Cambridge, MA: Harvard University Press.

Bourdieu, P. (1984/1988). Homo academicus. Stanford, CA: Stanford University Press.

Bourdieu, P. (1999). Acts of resistance: Against the tyranny of the market. New York: New Press.

Bourdieu, P., \& Wacquant, L. J. D. (1992). An invitation to reflexive sociology. Chicago, IL: University of Chicago Press.

Brint, S. (1984). "New-Class" and cumulative trend explanations of the liberal political attitudes of professionals. 
American Journal of Sociology, 90, 30-71.

Brooks, D. (2000). Bobos in paradise: The new upper class and how they got there. New York: Simon \& Schuster.

Bruce-Briggs, B. (Ed.). (1979). The New Class? New Brunswick, NJ: Transaction.

Brym, R. J. (1987). The political sociology of intellectuals: A critique and a proposal. In A. G. Gagnon (Ed.), The role of intellectuals in liberal democracies: political influence and social involvement. New York: Praeger. pp. 199-209.

Brym, R. J. (2001). Intellectuals, Sociology of. In N. Smelser, \& P. Baltes (Eds.), International encyclopedia of the social and behavioral sciences. Oxford, UK: Elsevier Science. pp. 7631-7635.

Cahm, E. (1996). The Dreyfus Affair in French society and politics. London, UK: Longman.

Camic, C. (1983). Experience and enlightenment: Socialization for cultural change in eighteenth-century Scotland. Chicago, IL: University of Chicago Press.

Camic, C., \& Gross, N. (2001). The new sociology of ideas. In J. R. Blau (Ed.), The Blackwell companion to sociology (pp. 236-249). Malden, MA: Blackwell.

Caute, D. (1966). The Left in Europe since 1789. New York: McGraw-Hill.

Chomsky, N. (1967). The responsibility of intellectuals. The New York Review of Books, 8.

Collini, S. (2006). Absent minds: intellectuals in Britain. New York: Oxford University Press.

Collins, R. (1998). The sociology of philosophies: A global theory of intellectual change. Cambridge, MA: Harvard University Press.

Collins, R. (2005). Sociology and philosophy. In C. Calhoun, C. Rojek, and B. Turner (Eds.), The Sage handbook of sociology. Thousand Oaks, CA: Sage. pp. 61-78.

Confino, M. (1972). On intellectuals and intellectual traditions in eighteenth- and nineteenth-century Russia. Daedalus, 101, 117-149.

Coser, L. A. (1965/1970). Men of ideas: a sociologist's view. New York: Free Press.

Drucker, P. F. (1969). The age of discontinuity: Guidelines to our changing society. New York: Harper \& Row.

Durkheim, É. (1893/1984). The division of labor in society. New York: Free Press.

Ehrenrench, B., \& Ehrenreich, J. (1979). The professional-managerial class. In P. Walker (Ed.), Between labor and capital. Boston, MA: South End. pp. 5-45.

Eyal, G. (2003). The origins of postcommunist elites: From Prague Spring to the breakup of Czechoslovakia. Minneapolis, MN: University of Minnesota Press.

Eyal, G., Szelényi, I., \& Townsley, E. (1998). Making capitalism without capitalists: The new ruling elites in Eastern Europe. New York: Verso.

Eyerman, R. (1994). Between culture and politics: Intellectuals in modern society. Cambridge, UK: Polity.

Forgacs, D. (1988/2000). Introduction to "Intellectuals and education". In D. Forgacs (Ed.), The Antonio Gramsci reader: Selected writings 1916-1935. New York: New York University Press. pp. 300-301.

Foucault, M. (1977/1994). Truth and power. In Power. New York: New Press. pp. 111-133.

Foucault, M., \& Deleuze, G. (1972/1973). The intellectuals and power: A discussion between Michel Foucault and Gilles Deleuze. Telos, 16, 103-109.

Fourcade, M. (2009). Economists and societies: Discipline and profession in the United States, Britain, and France, 1890s to 1990s. Princeton, NJ: Princeton University Press.

Franz, D. (2007). Intellectuals and public responsibility. Hedgehog Review, 9, 98-104.

Fuchs, S. (2001). Against essentialism: A theory of culture and society. Cambridge, MA: Harvard University Press.

Giddens, A. (1986). The constitution of society: Outline of the theory of structuration. Berkeley, CA: University of California Press.

Goldfarb, J. C. (1998). Civility and subversion: The intellectual in democratic society. New York: Cambridge University Press. 
Gouldner, A. W. (1978a). The New Class project, I: A frame of reference, theses, conjectures, arguments, and an historical perspective on the role of intellectuals and intelligentsia in the international class contest of the modern era. Theory and Society, 6, 153-203.

Gouldner, A. W. (1978b). The New Class project, II: A frame of reference, theses, conjectures, arguments, and an historical perspective on the role of intellectuals and intelligentsia in the international class contest of the modern era. Theory and Society, 6, 343-389.

Gramsci, A. (1932/2000). Intellectuals and education. In D. Forgacs (Ed.), The Antonio Gramsci reader: Selected writings 1916-1935. New York: New York University Press. pp. 300-322.

Gross, N. (2008). Richard Rorty: The making of an American philosopher. Chicago, IL: University of Chicago Press.

Hacker, A. (1979). Two "New Classes" or none? In B. Bruce-Briggs (Ed.), The New Class?. New York: McGraw-Hill. pp. 155-168.

Hansen, G. E. (1969). Intellect and power: Some notes on the intellectual as a political type. Journal of Politics, 31, 311-328.

Hayek, F. A. (1948/1949). The Intellectuals and socialism. University of Chicago Law Review, 16, 417-433.

Hofstadter, R. (1963). Anti-intellectualism in American life. New York: Alfred A. Knopf.

Hollander, P. (1981). Political pilgrims: Western intellectuals in search of the good society. New York: Harper Colophon.

Jacoby, R. (1987). The last intellectuals: American culture in the age of academe. New York: Basic Books.

James, W. (1907/1912). The social value of the college-bred. In Memories and studies. New York: Longmans, Green. pp. 309-325.

Judt, T. (1992). Past imperfect: French intellectuals, 1944-1956. Berkeley, CA: University of California Press.

Kadushin, C. (1974). American intellectual elite. Boston, MA: Little, Brown.

Karabel, J. (1996). Towards a theory of intellectuals and politics. Theory and Society, 25, 205-233.

Kellner, H., \& Heuberger, F. W. (Eds.). (1992). Hidden technocrats: The New Class and new capitalism. New Brunswick, NJ: Transaction.

Kennedy, M. D. (1991). Professionals, power and solidarity in poland: A critical sociology of Soviet-type society. New York: Cambridge University Press.

King, L. P., \& Szelényi, I. (2004). Theories of the New Class: intellectuals and power. Minneapolis, MN: University of Minnesota Press.

Kingston, P. W. (2000). The classless society. Stanford, CA: Stanford University Press.

Konrád, G, \& Szelényi, I. (1979). The intellectuals on the road to class power. New York: Harcourt Brace Jovanovich.

Kristol, I. (1978). Two cheers for capitalism. New York: Basic Books.

Kritzman, L. D. (2006). The Intellectual. In L. D. Kritzman (Ed.), The Columbia history of twentieth-century French thought. New York: Columbia University Press. pp. 363-374.

Kurzman, C. (2008). Democracy denied, 1905-1915: Intellectuals and the fate of democracy. Cambridge, MA: Harvard University Press.

Kurzman, C., \& Owens, L. (2002). The sociology of intellectuals. Annual Review of Sociology, 28, 63-90.

Ladd, E. C., Jr., \& Lipset, S. M. (1975). The divided academy: Professors and politics. New York: McGraw-Hill.

Lamont, M. (1992). Money, morals, and manners: The culture of the French and the American upper-middle class. Chicago, IL: University of Chicago Press.

Lenin, V. I. (1902/1975). What is to be done? Burning questions of our movement. In R. C. Tucker (Ed.), The Lenin anthology. New York: W. W. Norton. pp. 12-114.

Lipset, S. M. (1960/1981). Political man: The social bases of politics. Baltimore, MD: Johns Hopkins University Press. 
Malia, M. E. (1961). What is the intelligentsia? In R. Pipes (Ed.), The Russian intelligentsia. New York: Columbia University Press. pp. 1-18.

Mannheim, K. (1929/1936). Ideology and utopia: An introduction to the sociology of knowledge. London, UK: Kegan Paul.

Mannheim, K. (1936/1956). The problem of the intelligentsia: An enquiry into its past and present role. In Essays on the sociology of culture. London, UK: Kegan Paul. pp. 91-170.

Mao Tse-tung. (1926/1965). Analysis of the classes in Chinese society. In Selected works of Mao Tse-tung, Volume I. Peking, China: Foreign Languages Press. pp. 13-21.

Martin, B., \& Szelényi, I. (1987). Beyond cultural capital: Toward a theory of symbolic domination. in R. Eyerman, L. G. Svensson, \& T. Söderqvist (Eds.), Intellectuals, universities, and the state in western modern societies. Berkeley, CA: University of California Press. pp. 16-49.

Marx, K. (1844/2002). Critique of Hegel's philosophy of right. In J. C. Raines (Ed.), Marx on religion. Philadelphia, PA: Temple University Press. pp. 170-182.

Marx, K., \& Engels, F. (1932/1970). The German ideology (Part 1, with selections from Parts 2 and 3 and supplementary texts). New York: International.

Mead, G. H. (1934). Mind, self, and society: From the standpoint of a social behaviorist. Chicago, IL: University of Chicago Press.

Merton, R., \& Kitt, A. (1950). Contribution to the theory of reference group behaviour. In R. K. Merton \& P. F. Lazarsfeld (Eds.), Continuities in social research: Studies in the scope and method of "The American soldier". Glencoe, IL: Free Press. pp. 40-150.

Mills, C. W. (1951). White collar: The american middle classes. New York: Oxford University Press.

Misztal, B. A. (2007). Intellectuals and the public good: Creativity and civil courage. New York: Cambridge University Press.

Niebuhr, Reinhold. (1960). Liberals and the Marxist heresy. In G. B. de Huszar (Ed.), The intellectuals: A controversial portrait. Glencoe, IL: Free Press. pp. 302-307.

Nozick, R. (1986). "Why do intellectuals oppose capitalism?" In C. E. Aronoff, \& J. L. Ward (Eds.), The future of private enterprise. Atlanta, GA: Business Pub. Division, College of Business Administration, Georgia State University.

Parsons, T. (1969). "The intellectual": A social role category. In P. Rieff (Ed.), On intellectuals: Theoretical studies/Case studies. Garden City, NY: Anchor/Doubleday. pp. 3-24.

Podhoretz, N. (1979). "The adversary culture and the new class.” In B. Bruce-Briggs (ed.), The New Class? (pp. 19-31). New York: McGraw-Hill.

Ringer, F. K. (1969). The decline of the German mandarins: The German academic community, 1890-1933. Cambridge, MA: Harvard University Press.

Ringer, F. K. (1990). The intellectual field, intellectual history, and the sociology of knowledge. Theory and Society, 19, 269-294.

Rosenberg, M. (1979). Conceiving the self. New York: Basic Books.

Rueschemeyer, D. (2009). Usable theory: Analytical tools for social and political research. Princeton, NJ: Princeton University Press.

Said, E. W. (1994). Representations of the intellectual: The 1993 Reith lectures. New York: Pantheon.

Schumpeter, J. A. (1942/1950). Capitalism, socialism and democracy. New York: Harper \& Brothers.

Shils, E. (1958/1972). The intellectuals and the power: Some perspectives for comparative analysis. In The intellectuals and the powers and other essays. Chicago, IL: University of Chicago Press. pp.3-22.

Singer, E. (1981). Reference groups and social evaluations. In M. Rosenberg, \& R. H. Turner (Eds.), Social psychology: Sociological perspectives. New York: Basic Books. pp. 66-93.

Smith, C. (1998). American evangelicalism: Embattled and thriving. Chicago, IL: University of Chicago Press.

Sunstein, C. R. (2009). Going to extremes: How like minds unite and divide. New York: Oxford University Press.

Swartz, D. (1997). Culture and power: The sociology of Pierre Bourdieu. Chicago, IL: University of Chicago 
Press.

Szelényi, I, \& Martin, B. (1988). The Three waves of New Class theories. Theory and Society, 17, 645-667.

Tocqueville, A. d. (1856/1998). The old regime and the revolution, Volume I: The Complete Text. Chicago, IL: University of Chicago Press.

Torpey, J. C. (1995). Intellectuals, socialism, and dissent: the East German opposition and its legacy. Minneapolis, MN: University of Minnesota Press.

Verdery, K. (1991a). National ideology under socialism: Identity and cultural politics in Ceauşescu's Romania. Berkeley, CA: University of California Press.

Verdery, K. (1991b). Theorizing socialism: A prologue to the "transition”. American Ethnologist, 18, 419-439.

Walker, P. (Ed.). (1979a). Between labor and capital. Boston, MA: South End.

Walker, P. (1979b). Introduction. In P. Walker (Ed.), Between labor and capital. Boston, MA: South End. pp. XIII-XXX.

Waters, M. (1991). Collapse and convergence in class theory: The return of the social in the analysis of stratification arrangements. Theory and Society, 20, 141-172.

Weber, M. (1919/1946). Science as a vocation. In H. H. Gerth, \& C. W. Mills (Eds.), From Max Weber: Essays in sociology. New York: Oxford University Press. pp. 129-156.

Weber, M. (1922/1963). The sociology of religion. Boston, MA: Beacon.

Wright, E. O. (1979). Intellectuals and the class structure of capitalist society. In P. Walker (ed.), Between labor and capital. Boston, MA: South End. pp. 191-212.

Wrong, D. H. (1983/1998). The New Class: Does it exist? In The modern condition: Essays at century's end. Stanford, CA: Stanford University Press. pp. 99-113.

\section{Notes}

Note 1. In 2008, the author conducted an online search for syllabi on "sociology of intellectuals" with zero results.

Note 2. See Collini (2006: 57) for a critique of Bourdieu's theoretical scheme of intellectuals.

Note 3. Karl Marx did not use the term "intellectual," but rather used the "Mann der Wissenschaft," which can be translated as "man of science" and refers to intellectuals loosely in the modern sense (Berman 1982: 115).

Note 4. Gramsci uses the word "collective intellectual" to refer to the Leninist party specifically, but the concept can have a broader implication.

Note 5. Obviously Shils has a quite broad definition of intellectuals.

Note 6. Collins's concept of intellectual attention space is indeed similar to Bourdieu's intellectual field. 